\title{
Exploring the Relational Impact of Service Quality on Customer Satisfaction
}

\author{
Manish Kumar Yadav*and Alok Kumar Rai ${ }^{\dagger}$
}

\section{Abstract:}

Customer Satisfaction has been a psychological attribute inviting attention of the customers and requiring decipher their contribution in overall business performance. Banking has been no exception to this phenomenon. Many Literatures have found a strong relationship between service quality and customer satisfaction in service sector in general and banking industry in particular. The aim of the study is to investigate the relationship between service quality and customer satisfaction. The study assesses the level of customers' satisfaction and service quality performance of the select banks. Further the study compares the satisfaction and service quality in select public and private sector banks. The study also identifies the area where the banks need to focus. The research design is descriptive as the research is intended to conclude and suggest measures to zero down on the service quality gaps in select public and private sector banks. The result shows a positive relationship between service quality and customer satisfaction. Service quality dimensions (tangibility, reliability, responsiveness, assurance and empathy) show wide service quality gaps. The comparative study of public sector banks and private sector banks show superiority of private sector banks over public sector banks in customer satisfaction and performance of service delivery.

\footnotetext{
* Research Scholar, Faculty of Management Studies, Banaras Hindu University, Varanasi-221005; mnsfms@gmail.com

† Professor, Faculty of Management Studies, Banaras Hindu University, Varanasi-221005; alok.fmsbhu@gmail.com
} 
Keywords: Service Quality, Customer Satisfaction, Public Sector bank, Private Sector bank

\section{Introduction}

Customer satisfaction refers to the extent which customers are satisfied with the products and services provided by a business. Customer satisfaction is important because when a customer is happy with a service or goods provider, they are most likely to be loyal and to make repeat orders. When customers use a wide range of services offered by a business then it helps to increase the profit margin of the company. In this accordance Wilson et al. (2008) demonstrated that service quality (Sivadas\& Baker-Prewitt 2000; Kotler \& Keller 2009), price, personal and situational factors are the determinant of customer satisfaction.

\section{Review of Literature}

Marketing researchers have shown the importance of satisfaction and service quality, and indicated these constructs as indices of competitive benefit in organizations (Ruyter, 1997). Various authors (Fornell et al., 1996; Spreng and Mackoy, 1996; Andreassen and Lindestad, 1998; Oliver, 1999; Cronin et al, 2000; Saha and Theingi, 2009; Yang et al., 2009; Deng et al, 2010; Wang, 2010; Chang and Wang, 2011; Edward \&Sahadev, 2011) have found that service quality has significant effect on customer satisfaction. Yi (1990) established that service quality is a vital determinant of customer satisfaction. The nature of service quality and customer satisfaction link has largely been viewed as linear in most of the researches which demonstrate that higher levels of service quality results in higher level of customer satisfaction (Pollack, 2008). Shin and Kim (2008) identified that service quality is a customer's overall impression of the relative efficiency of the service provider. They stated that service quality is significantly related to customer satisfaction. It has also been found that service quality positively influences customer satisfaction in different industries viz. retailing (Johnson \&Fornell, 1991; Kristensen et al., 1999; Cronin et al., 2000), website and online shopping (Kuo, 2003; Lee \& Lin, 2005; Collier \&Bienstock, 2006; Hsu, 2006; Park \& Kim, 2006; Bauer et al., 2006) 
and telecom industry (Wang et al. (2004); Kim et al. (2004); Tung (2004); Turel and Serenko (2006)). Jiang and Wang (2006) concluded that there exists a significant role of perceived service quality in customer satisfaction but also indicated that the conditions under different dimensions of effect may or may not influence service quality evaluation and customer satisfaction. Jamali, (2007) found a positive relationship between service quality and customer satisfaction. Iglesias and Guillen, (2004) revealed that perceived quality had a direct and positive influence on the level of customer satisfaction. Wan Normila Mohamad et al., (2013) found that tangibility; reliability and assurance, the determinants of service quality, are important predictors of customer satisfaction. Bitner (1990) \& Bolton and Drew (1991) have suggested that customer satisfaction is an antecedent of service quality. From the review of literature it is found that service quality is an important dimension of customer satisfaction (Singh 2013).

The relationship between service quality and customer satisfaction has been established in banking industry too. Caruana (2002) based on his study conducted in banking industry concluded that service quality effects customer satisfaction. Malik (2012) revealed that customer satisfaction is significantly related to perceived service quality. Literatures (Arasli et al., 2005; Levesque and McDougall, 1996; Jamal and Naser, 2002) have found that service quality positively effects customer satisfaction in banking industry.

Ding Hooi Ting, (2004) found that service quality is the antecedent of satisfaction and purported a curvilinear relationship between these two constructs. Jeroen J. L. Schepers (2010) found that relationship between service quality and satisfaction is nonlinear and quality improvements have an asymmetric effect on satisfaction. Mun et al., (2010) in their study also found that the dimensions of service quality (Empathy, Responsiveness, Assurance) had positive relationship but no significant effect on customer satisfaction. 


\section{Bank Profile}

For the purpose of this study two leading bank were selected. One bank from public sector and one bank from private sector has been considered. The profiles of these two banks are below.

\section{State Bank of India (SBI)}

The evolution of State Bank of India can be traced back to the first decade of the 19th century. Itcommenced with the establishment of the Bank of Calcutta in Calcutta, on 2 June 1806. The bank was redesigned as the Bank of Bengal on 2 January 1809. It was the first ever joint-stock bank of the British India, established under the sponsorship of the Government of Bengal. Subsequently, the Bank of Bombay, the Bank of Madras and the Bank of Bengal were amalgamated to form the Imperial Bank of India, on 27 January 1921.

The First Five year plan, in 1951, aimed at serving the Indian economy in general and the rural sector of the country, in particular. To meet this goal, the All India Rural Credit Survey Committee,established on 1 July 1955, recommended the formation of a state-partnered and state-sponsored bank.

The All India Rural Credit Survey Committee proposed the takeover of the Imperial Bank of India, and integrated with the former state-owned or state-associate banks. Subsequently, an act was passed in the Parliament of India in May 1955. As a result, the State Bank of India (SBI) was established on 1 July 1955.

\section{Branches}

The corporate center of SBI is located in Mumbai. In order to cater to different functions, there are several other establishments in and outside Mumbai, apart from the corporate center. The bank boasts of having as many as 14 local head offices and 57 Zonal Offices, located at major cities throughout India. It is recorded that SBI has about 10000 branches, well networked to cater to its customers throughout India.

\section{ATM Services}

SBI provides easy access to money to its customers through more than 8500 ATMs in India. The Bank also facilitates the free 
transaction of money at the ATMs of State Bank Group, which includes the ATMs of State Bank of India as well as the Associate Banks - State Bank of Bikaner \& Jaipur, State Bank of Hyderabad, State Bank of Indore, etc. You may also transact money through SBI Commercial and International Bank Ltd by using the State Bank ATM-cum-Debit (Cash Plus) card.

\begin{tabular}{|c|c|c|}
\hline Subsidiaries Bank & $\begin{array}{c}\text { Products and } \\
\text { ServicesPersonal } \\
\text { Banking }\end{array}$ & Other Services \\
\hline $\begin{array}{l}\text { State Bank of } \\
\text { Bikaner and Jaipur } \\
\text { (SBBJ), } \\
\text { State Bank of } \\
\text { Hyderabad (SBH), } \\
\text { State Bank of India } \\
\text { (SBI), } \\
\text { State Bank of } \\
\text { Indore (SBIR), } \\
\text { State Bank of } \\
\text { Mysore (SBM), } \\
\text { State Bank of } \\
\text { Patiala (SBP), } \\
\text { State Bank of } \\
\text { Saurashtra (SBS), } \\
\text { State Bank of } \\
\text { Travancore (SBT) }\end{array}$ & $\begin{array}{l}\text { SBI Term Deposits, } \\
\text { SBI Loan for } \\
\text { Pensioners, } \\
\text { SBI Recurring, } \\
\text { Deposits Loan } \\
\text { Against, Mortgage of } \\
\text { Property, } \\
\text { SBI Housing Loan, } \\
\text { Loan against Shares \& } \\
\text { Debentures, } \\
\text { SBI Car Loan Rent } \\
\text { Plus Scheme, } \\
\text { SBI Educational Loan } \\
\text { Medi-Plus Scheme }\end{array}$ & $\begin{array}{l}\text { Agriculture/Rural } \\
\text { Banking, } \\
\text { NRI Services, } \\
\text { ATM Services, } \\
\text { demat Services, } \\
\text { Corporate Banking, } \\
\text { Internet Banking, } \\
\text { Mobile Banking, } \\
\text { International Banking, } \\
\text { Safe Deposit Locker, } \\
\text { RBIEFT, E-Pay, E-Rail, } \\
\text { SBI VishwaYatra, } \\
\text { Foreign Travel } \\
\text { Card,Broking } \\
\text { Services,Gift Cheques }\end{array}$ \\
\hline
\end{tabular}

Source:https://www.sbi.co.in/

\section{ICICI Bank}

ICICI bank started as a wholly owned subsidiary of ICICI Limited, an Indian financial institution, in 1994. Four years later, when the company offered ICICI Bank's shares to the public, ICICI's shareholding was reduced to $46 \%$. In the year 2000, ICICI bank made an equity offering in the form of ADRs on the New York Stock Exchange (NYSE), thereby becoming the first Indian company and the first bank or financial institution from non-Japan Asia to be listed on the NYSE. In the next year, it acquired the Bank of Madura Limited in an all-stock amalgamation. Later in the year 
and the next fiscal year, the bank made secondary market sales to institutional investors. With a change in the corporate structure and budding competition in the Indian Banking industry, the management of both ICICI and ICICI Bank were of the opinion that a merger between the two entities would prove to be an essential step. It was in 2001 that the Boards of Directors of ICICI and ICICI Bank sanctioned the amalgamation of ICICI and two of its whollyowned retail finance subsidiaries, ICICI Personal Financial Services Limited and ICICI Capital Services Limited, with ICICI Bank. In the following year, the merger was approved by its shareholders, the High Court of Gujarat at Ahmadabad as well as the High Court of Judicature at Mumbai and the Reserve Bank of India.

\section{Branches \& ATMs}

ICICI Bank has a wide network both in Indian and abroad. In India alone, the bank has 1,420 branches and about 4,644 ATMs. Talking about foreign countries, ICICI Bank has made its presence felt in 18 countries - United States, Singapore, Bahrain, Hong Kong, Sri Lanka, Qatar and Dubai International Finance Centre and representative offices in United Arab Emirates, China, South Africa, Bangladesh, Thailand, Malaysia and Indonesia. The Bank proudly holds its subsidiaries in the United Kingdom, Russia and Canada out of which, the UK subsidiary has established branches in Belgium and Germany.

\begin{tabular}{|l|l|l|}
\hline \multicolumn{3}{|c|}{ Products \& Services } \\
\hline Personal Banking & NRI Banking & Business Banking \\
Deposits & Money Transfer & Corporate Net Banking \\
Loans & Bank Accounts & Cash Management \\
Cards & Investments & Trade Services \\
Investments & Property & FXOnline \\
Insurance & Solutions & SME Services \\
Demat Services & Insurance & Online Taxes \\
Wealth & Loans & Custodial Services \\
Management & & \\
\hline
\end{tabular}




\section{Research Problem}

From the above literatures the various writers (Saha and Theingi, 2009; Chang and Wang, 2011; Andreassen and Lindestad, 1998; Chang and Wang, 2011; Cronin et al, 2000; Deng et al, 2010; Fornellet al., 1996; Edward \&Sahadev, 2011; Oliver, 1999; Spreng and Mackoy, 1996; Yang et al., 2009; Wang, 2010) have found a significant relationship between service quality and customer satisfaction. These studies also explored the nature of the relationship is linear but few researchers (Cheung and Lee, 2005; Jeroen J. L. Schepers, 2010) have contradicted and opined that the nature of relationship is curvilinear. Some researchers found that even though this relationship is positive but not significant (Mun et al., 2010).

\section{Research Hypothesized Model}

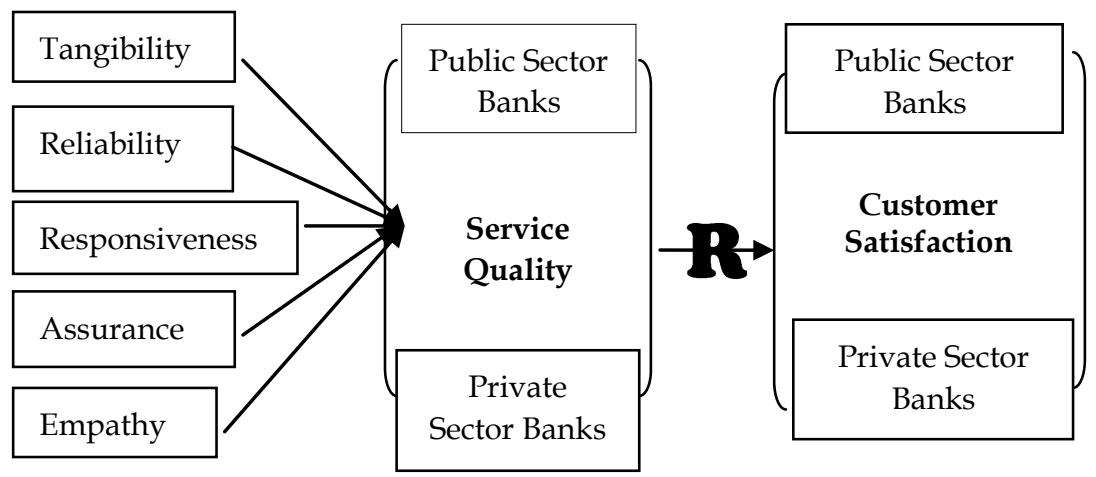

Aim of the study:The aim of the study is to investigate the impact of service quality on customer satisfaction in banking industry. This study also explores the difference in the impact of service quality on customer satisfaction in public and private sector banks.

Research Objectives:The study has following objectives:

1. To assess the service quality of select public and private sector banks.

2. To compare the service quality in select public and private banks. 
3. To assess the customer satisfaction of select public and private sector banks.

4. To compare the customer satisfaction in select public and private bank.

5. To investigate the impact of service quality on customer satisfaction in banking.

6. To compare the difference in the impact of service quality on customer satisfaction in select public and private banks.

\section{Hypothesis:}

1.1 There is no significant difference in the customer's perception on dimensions (tangibility, reliability, responsiveness, assurance and empathy) of select public and private banks.

$$
\text { Ho: } \mu_{(T, R, R e, A, E) ~ p u b}=\mu(T, R, R e, A, E) \text { pvt }
$$

1.2 There is no significant difference in service quality of public and private bank.

$$
\text { Ho: } \mu_{\text {SQpub }}=\mu_{\text {sQpvt }}
$$

1.3 There is no significant difference in customer satisfaction of select public and private bank.

$$
\text { Ho: } \mu_{\mathrm{SApub}}=\mu_{\mathrm{SApvt}}
$$

1.4 There is no significant relationship between service quality and customer satisfaction.

$$
\mathrm{r}=0
$$

1.5 There is no significant difference in the impact of service quality on customer satisfaction in public and private sector banks.

Ho: $\mu_{\text {Rpub }}=\mu_{\text {Rpvt }}$

\section{Research Method}

The modified SERVQUAL (Parasuramanet al., 1988) was used to collect the primary data. Theresponses were obtained on a 5 point Likert type scales with anchor points from strongly disagree to strongly agree. The study is descriptive in nature. The sampling has 
been done through two leading Indian banks according to March 2012 (one from public bank and one from private bank) customer havesaving account/currentholders who wereusing at least two products that have business transaction over two lakhs over three consecutive years. Through snow ball sampling technique100 respondents from selectedbanks have been taken and the questionnaire was also tested for its reliability with the Cronbach alpha value (.808) which proved the reliability of the questionnaire.

Findings:The findings from the study are following

Table (1)

\begin{tabular}{|l|c|c|}
\hline \multicolumn{1}{|c|}{ Dimensions } & Percentage & Gap Percentage \\
\hline Tangibility & 70.7 & 29.3 \\
\hline Reliability & 71.2 & 28.8 \\
\hline Responsiveness & 68.5 & 31.5 \\
\hline Assurance & 69.8 & 30.2 \\
\hline Empathy & 67.14 & 32.86 \\
\hline
\end{tabular}

It is evident (Table 1) that the respondents are agree with performance provided on tangibility is $71.2 \%$, reliability is $71.2 \%$, responsiveness is $68.5 \%$ assurance is $69.8 \%$ and empathy dimension is $67.14 \%$ which brings forth the fact that there are still $29.3 \%$ with tangibility, $28.8 \%$ with reliability $31.5 \%$ with responsiveness, $30.2 \%$ $\mathrm{s}$ with assurance and $32.86 \%$ with empathy are left to be worked upon.

Table (2)

\begin{tabular}{|c|l|c|c|}
\hline \multirow{2}{*}{ Sr.no } & \multirow{2}{*}{ Dimensions } & \multicolumn{2}{|c|}{ Service Quality Gaps } \\
\cline { 3 - 4 } & & Public Bank & Private bank \\
\hline 1 & Tangibility & $-33.1 \%$ & $-24.5 \%$ \\
\hline 2 & Reliability & $-29.76 \%$ & $-27.84 \%$ \\
\hline 3 & Responsiveness & $-32.70 \%$ & $-30.30 \%$ \\
\hline 4 & Assurance & $-31.6 \%$ & $-28.80 \%$ \\
\hline 5 & Empathy & $-34.4 \%$ & $-31.32 \%$ \\
\hline
\end{tabular}

It is clear (Table 2) that there are $33.1 \%, 29.76 \%, 32.70 \%, 31.6 \%$ and $34.4 \%$ agree with service performance on respective dimensions are left to be worked upon in public bank and $24.5 \%, 27.84 \%, 30.30 \%$, 
$28.80 \%$ and $31.32 \%$ agreement with respective dimension are left to be worked in private banks.

Table (3) Hypothesis Testing

\begin{tabular}{|c|c|c|c|c|c|}
\hline Dimensions & Banks & Score & & $\begin{array}{c}\text { t-test } \\
\text { signific } \\
\text { ance } \\
\text { level }\end{array}$ & Result \\
\hline \multirow[t]{2}{*}{ Tangibility } & $\begin{array}{c}\text { Public } \\
\text { Bank }\end{array}$ & $66.9 \%$ & \multirow{2}{*}{$12.60 \%$} & \multirow{2}{*}{.00} & \multirow{2}{*}{$\begin{array}{c}\mathrm{H}_{0} \text { Reject } \\
\text { ed }\end{array}$} \\
\hline & $\begin{array}{c}\text { Private } \\
\text { Bank }\end{array}$ & $74.5 \%$ & & & \\
\hline \multirow[t]{2}{*}{ Reliability } & $\begin{array}{l}\text { Public } \\
\text { Bank }\end{array}$ & $70.24 \%$ & \multirow{2}{*}{$1.92 \%$} & \multirow[t]{2}{*}{.089} & \multirow{8}{*}{$\begin{array}{c}\mathrm{H}_{0} \\
\text { Can } \\
\text { not } \\
\text { be } \\
\text { Rejected }\end{array}$} \\
\hline & $\begin{array}{c}\text { Private } \\
\text { Bank }\end{array}$ & $72.16 \%$ & & & \\
\hline \multirow[t]{2}{*}{$\begin{array}{l}\text { Responsiven } \\
\text { ess }\end{array}$} & $\begin{array}{c}\text { Public } \\
\text { Bank }\end{array}$ & $67.30 \%$ & \multirow{2}{*}{$2.40 \%$} & \multirow{2}{*}{.174} & \\
\hline & $\begin{array}{c}\text { Private } \\
\text { Bank }\end{array}$ & $69.7 \%$ & & & \\
\hline \multirow[t]{2}{*}{ Assurance } & $\begin{array}{c}\text { Public } \\
\text { Bank }\end{array}$ & $68.4 \%$ & \multirow{2}{*}{$2.80 \%$} & \multirow{2}{*}{130} & \\
\hline & $\begin{array}{c}\text { Private } \\
\text { bank }\end{array}$ & $71.2 \%$ & & & \\
\hline \multirow[t]{2}{*}{ Empathy } & $\begin{array}{c}\text { Public } \\
\text { bank }\end{array}$ & $65.6 \%$ & \multirow{2}{*}{$3.08 \%$} & \multirow{2}{*}{.085} & \\
\hline & $\begin{array}{c}\text { Private } \\
\text { bank }\end{array}$ & $68.68 \%$ & & & \\
\hline \multirow[t]{2}{*}{$\begin{array}{l}\text { Overall } \\
\text { Satisfaction }\end{array}$} & $\begin{array}{c}\text { Public } \\
\text { bank }\end{array}$ & 3.760 & \multirow{2}{*}{.3200} & \multirow{2}{*}{.001} & \multirow{2}{*}{$\begin{array}{c}\mathrm{H}_{0} \text { Reject } \\
\text { ed }\end{array}$} \\
\hline & $\begin{array}{c}\text { Private } \\
\text { bank }\end{array}$ & 4.080 & & & \\
\hline \multirow[t]{2}{*}{$\begin{array}{l}\text { Service } \\
\text { Quality }\end{array}$} & $\begin{array}{c}\text { Public } \\
\text { bank }\end{array}$ & 3.3844 & \multirow{2}{*}{.1780} & \multirow{2}{*}{.001} & \multirow{2}{*}{$\begin{array}{c}\mathrm{H}_{0} \text { Reject } \\
\text { ed }\end{array}$} \\
\hline & $\begin{array}{c}\text { Private } \\
\text { bank }\end{array}$ & 3.5624 & & & \\
\hline
\end{tabular}


The table (3) indicatedthat gap between private bank and public bank on reliability, responsiveness, assurance, and empathy are not significant and this shows that the gaps were only due to chance. Thus the statistics show that null hypothesis cannot be rejected for four dimensions of service quality. But gaps on tangibility dimension, overall customer satisfaction and service quality are significant (significance value is less than the default value).so we can't reject the hypothesis.

Table (4)

\begin{tabular}{|l|c|c|}
\hline \multicolumn{1}{|c|}{ Dimensions } & $\begin{array}{c}\text { Overall } \\
\text { Satisfaction }\end{array}$ & $\begin{array}{c}\text { Significance } \\
\text { value }\end{array}$ \\
\hline Tangibility & $.303^{* *}$ & .000 \\
\hline Reliability & $.369^{* *}$ & .000 \\
\hline Responsiveness & $.589^{* *}$ & .000 \\
\hline Assurance & $.574^{* *}$ & .000 \\
\hline Empathy & $.435^{* *}$ & .000 \\
\hline
\end{tabular}

It is evident (Table 4) that all the dimensions have significant relationship with customers' satisfaction. Assurance and Responsiveness have moderate relationship with satisfaction but tangibility has weak relationship with customer satisfaction. Further a mathematical modeling has been established in service quality and customer satisfaction with resulted statistics and estimate. The predicting strength of $\mathrm{R}^{2}(52.1 \%)$ and a small standard estimate (.25946)shows the good strength of model fit. In public sector bank predicting strength of service quality (.603) is greater than the strength (.392) to predict the customers' satisfaction.

\section{Conclusion}

This suggests that private sector differ from the public banks on the tangibility dimension and overall satisfaction and service quality. The service quality of private bank is greater than the quality provide by public bank. The study also indicates that private bank customers are enjoying more in term of satisfaction in comparison with his competitor public bank.Further the study explore that service quality has significant positive linear relationship with 
customer satisfaction (Saha and Theingi, 2009; Chang and Wang, 2011; Andreassen and Lindestad, 1998; Chang and Wang, 2011; Cronin et al, 2000; Deng et al, 2010; Fornellet al., 1996; Edward \&Sahadev, 2011; Oliver, 1999; Spreng and Mackoy, 1996; Yang et al., 2009; Wang, 2010).The study shows that the impact of service quality on customer satisfaction is differ for both the select public and private banks. Public bank shows a good impact on customer satisfaction in comparison with private bank. The service quality measurement dimensions show a big performancegap on all the five dimensions.Service quality dimensions assurance and responsiveness are two important dimensions of service quality contributing in satisfaction level of bank customers other three dimensions of service quality.

\section{References}

Arasli, H, TuranKatrircioglu, S., Mehtap-Smadi, S. (2005). A Comparison of Service Quality in the Banking Industry: Some Evidence from Turkish - and Greek - Speaking Areas in Cyprus. International Journal of Bank Marketing, 23(7), pp. 508526.

Bauer, H. H., Falk, T., Hammerschmidt, M., (2006). eTransQual: A Transaction Process-Based Approach for Capturing Service Quality in Online Shopping. Journal of Business Research, 59, 866875.

Bitner, M. J. (1990). Evaluating Service Encounters: The Effects of Physical Surroundings and Employee Responses. Journal of Marketing, 54(2), 69-82.

Bolton, R. N., Drew, J. H. (1991). A Multistage Model of Customers' Assessments of Service Quality and Value. Journal of Consumer Research, 55, 1-9.

Caruana, A. (2002). Service Loyalty: The Effects of Service Quality and the Mediating Role of Customer Satisfaction. European Journal of Marketing, 36(7), 811-828.

Chang HsinHsin, Wang Hsin-Wei, (2011). The Moderating Effect of

Customer Perceived Value on Online Shopping Behavior. Online Information Review, 35(3), 333 - 359.

Cheung, C.M.K., and Lee, M.K.O. (2003). An Integrative Model of Consumer Trust in Internet Shopping. European Conference on 
Information Systems (ECIS 2003), Naples, Italy.

Ding Hooi Ting, (2004). Service Quality and Satisfaction Perceptions: Curvilinear and Interaction Effect. International Journal of Bank Marketing, 22 (6), pp.407 - 420.

Collier, J.E., and Bienstock, C. (2006). Measuring Service Quality in E-Retailing. Journal of Service Research, 8(3), 260-275.

Cronin, J, Brady, M K and Hult, T M (2000). Assessing the Effects of Quality, Value and Customer Satisfaction on Consumer Behavioral Intentions in Service Environment. Journal of Retailing, 76(2), 193-218.

Deng, Z., Lu, Y., Wei, K.K. and Zhang, J. (2010). Understanding Customer Satisfaction and Loyalty: An Empirical Study of Mobile Instant Messages in China. International Journal of Information Management, Forthcoming issue, 30(4), 289-300.

Dima Jamali, (2007). A Study of Customer Satisfaction in the Context of a Public Private Partnership. International Journal of Quality \& Reliability Management, 24(4), 370 - 385.

Edward, M. \&Shahadev S. (2011). Role of Switching Cost in the Service Quality, Perceived Value, Customer Satisfaction and Customer Retention Linkage. Asia Pacific Journal of Marketing and Logistics, 75(3), 117-128.

Falk, T., Hammerschmidt, M., and Schepers, J.J.L. (2010). The Service Quality-Satisfaction Link Revisited: An Asymmetric and Dynamic Perspective. Journal of the Academy of Marketing Science, 38(3), 288-302.

Fornell, C., Johnson, M.D., Anderson, E.W., Cha, J. and Bryant, B.E. (1996). The American Customer Satisfaction Index: Nature, Purpose and Findings. Journal of Marketing, 60 (3), 7-18.

Hsu, J., and Hsu, C. (2008). The Relationships Between Service Quality and Customer Satisfaction in a Leading Chinese Web 2.0 Companies. The Business Review, Cambridge, 11(1), 84-89.

Jamal, A., Naser, K., 2002. Customer Satisfaction and Retail Banking: An Assessment of Some of the Key Antecedents of Customer Satisfaction in Retail Banking. International Journal of Bank Marketing, 20 (4), 146-160.

JayaramanMunusamy, Shankar Chelliah and Hor Wai Mun (2010). Service Quality Delivery and Its Impact on Customer Satisfaction in the Banking Sector in Malaysia. International Journal of Innovation, Management and Technology, 1(4), 398-404. 
Jiang, Y., \& Wang, C.L. (2006). The Impact of Affect on Service Quality and Satisfaction: The Moderation of Service Contexts. Journal of Services Marketing, 20(4), 211-218.

Johnson, M. D., \&Fornell, C. (1991). A Framework for Comparing Customer Satisfaction across Individuals and Product Categories. Journal of Economic Psychology, 12, 267 - 286.

K. De Ruyter, J. Bloemer and P. Pascal (1997). Merging Service Quality and Service Satisfaction: An Empirical Test of Integrative Model. Journal of Economic Psychology, 18 (14), 187406.

Kim, S., and Stoel, L. (2004). Apparel Retailers: Website Quality Dimensions and Satisfaction. Journal of Retailing and Consumer Services, 11(2), 109-117.

Kristensen, K., Martensen, A., \&Gronholdt, L. (1999). Measuring the Impact of Buying Behaviour on Customer Satisfaction. Total Quality Management, 10(4/5), 602-614.

Kuo, C. T. (1996). Study on Customer Satisfy of Swimming PoolUsing the Sample of National Chung Cheng University's Swimming Pool. Journal of Physical Education, 49-68.

Kuo, Y. F., 2003. A Study on Service Quality of Virtual Community Web Sites. Total Quality Management, 14 (4), 461-473.

Lee, G-G., Lin, H-F., (2005). Customer Perceptions of E-Service Quality in Online Shopping. International Journal of Retail $\mathcal{E}$ Distribution Management, 33 (2), 161-176.

Levesque, T., and McDougall, G. (1996). Determinants of Customer Satisfaction in Retail Banking. International Journal of Bank Marketing, 14(7), 12-20.

Marta Pedraja Iglesias, M. Jesus YagüeGuillén (2004). Perceived Quality and Price: Their Impact on the Satisfaction of Restaurant Customers. International Journal of Contemporary Hospitality Management, 16 (6), 373 - 379.

Oliver, R. L. (1999). When Consumer Loyalty? Journal of Marketing, 63(4), 33-44.

Parasuraman, A., Berry, L.L \&Zeithaml, V (1985). A Conceptual Model of Service Quality and the Implications for Future Research. Journal of Marketing Management, 49, 41-51

Parasuraman, A., Zeithaml, V.A. and Berry, L. (1988). SERVQUAL: A Multiple-Item Scale for Measuring Customer Perceptions of Service Quality. Journal of Retailing, 64(4), 12-40. 
Pollack, B.L. (2008). The Nature of the Service Quality and Satisfaction Relationship: Empirical Evidence for the Existence of Satisfiers and Dissatisfiers. Managing Service Quality, 18(6), 537-58.

Saha G. C; Theingi, (2009). Service Quality, Satisfaction, and Behavioral Intentions, Managing Service Quality. 19, 350-372.

SaifUllah Malik (2012). Customer Satisfaction, Perceived Service Quality and Mediating Role of Perceived Value. International Journal of Marketing Studies, 4 (1), 68-76.

Shin, D.H., \& Kim, W.-Y. (2008). Forecasting Customer Switching Intention in Mobile Service: An Exploratory Study of Predictive Factors in Mobile Number Portability. Technological Forecasting $\mathcal{E}$ Social Change, 75(6), 854-874.

Singh Ajmer (2012). Impact of Perceived Service Quality on Customer Loyalty Intentions in Retail Outlets. European Journal of Business and Management, 4(21), 138-149.

Spreng, R. A., and Mackoy, R. D. (1996). An Empirical Examination of a Model of Perceived Serviced Service Quality and Satisfaction. Journal of Retailing, 72(2), 201-214.

Tor WallinAndreassen, BodilLindestad, (1998). Customer Loyalty and Complex Services: The Impact of Corporate Image on Quality, Customer Satisfaction and Loyalty for Customers with Varying Degrees of Service Expertise. International Journal of Service Industry Management, 9(1), 7 - 23.

Tung, L. L. (2004). Service Quality and Perceived Value's Impact on Satisfaction, Intention and Usage of Short Message Service (SMS). Information Systems Frontiers, 6(4), 353-368.

Turel, O. and Serenko, A. (2006). Satisfaction with Mobile Services in Canada: An Empirical Investigation. Telecommunications Policy, 314-331.

Wang, C. Y.(2010). Service Quality, Perceived Value, Corporate Image, and Customer Loyalty in the Context of Varying Levels of Switching Costs. Psychology \& Marketing, 27, 252-262.

Yi, Y. (1990). A Critical Review of Customer Satisfaction. American Marketing Association, Chicago. 